\title{
Infectious and parasitic diseases of phytophagous insect pests in the context of extreme environmental conditions
}

\author{
Danail Takov ${ }^{1 *}$, Daniela Pilarska ${ }^{1,2}$, Andreas Linde ${ }^{3}$, Marek Barta ${ }^{4}$ \\ ${ }^{1}$ Institute of Biodiversity and Ecosystem Research - Bulgarian Academy of Sciences, 1 Tsar Osvoboditel Blvd, \\ BG-Sofia 1000, Bulgaria \\ ${ }^{2}$ New Bulgarian University, Department of Natural Sciences, BG-1618 Sofia, 21 Montevideo Str., Bulgaria \\ ${ }^{3}$ Eberswalde University for Sustainable Development, Alfred-Möller-Straße, DE - 16225 Eberswalde, Germany \\ ${ }^{4}$ Institute of Forest Ecology, Slovak Academy of Sciences, L. Štúra 2, SK-960 53 Zvolen, Slovak Republic
}

\begin{abstract}
The density of phytophagous insect pest populations is related (directly and indirectly) to several groups of factors that can be broadly divided into: abiotic, biotic and anthropogenic. Each extreme in the abiotic environment at a macro-level leads to a series of consecutive extremes in the biotic environment, which eventually results in micro-level responses in the individual organisms. The manifestation of factors acts in aggregate or in a sequence, creating a chain of processes around us. Insects very efficiently use the abundance of nutritional resources, resulting in a tremendous increase in their population density, and triggering control mechanisms through the emergence of parasitic and pathogenic infections (viruses, bacteria, fungi, microsporidia, protozoa and nematodes). The development of entomopathogenic infections in host populations is directly dependent on the characteristics of both the antagonist and the insect. It is associated with the lifestyle and life cycle of the insect, with features encoded in the mechanism of pathogen action, and limited by the pathogen's virulence and pathogenicity.
\end{abstract}

Key words: entomopathogenic infections; environmental conditions; extreme; insect pests; epizootic

Editor: Jaroslav Holuša

\section{Introduction}

Among animals, insects are the most numerous taxonomic group. They have occupied almost every ecological niche on the Earth and, therefore, studies of their ecological strategies, but also of control mechanisms is becoming increasingly important (Leibhold 2012). The advancement of industrialization and development of technology on one hand and increased consumption of goods and services by the world's population and at the same time accelerated mobility on other hand influence different ecosystems and their species composition and health. The high level of development in our societies and the need of minimizing the negative effects of human activity on nature as a whole, are becoming more important (Schowalter 2012). The global climate change is a fact and is increasingly manifested as extreme weather phenomena that affect large areas of the planet with direct impacts on the lives of large numbers of people
(Vitousek et al. 1997; Thomas et al. 2004; Burney \& Flannery 2005). The study of impacts of these factors on forest communities condition, which are habitats of various group of insects, is a major task for scientists. Sustainable management of natural resources involves implementation of measures which are environmentally friendly in all spheres of life.

Like in any organism, disease-causing agents are involved in the regulation of insect populations, and include viruses, bacteria, protozoans, microsporidia, fungi, and nematodes. Despite extensive research worldwide, there are still many unknowns about biological control mechanisms in insect populations. This review presents pathogen groups causing infection and parasite deseases in different forest and other insect pests in the context of extreme environmental conditions, cascade effect of the factors (abiotic, biotic and anthropogenic) and epizootic which finally can results as natural mechanisms of insect regulation. 


\section{Environmental factors are the basis for triggering biological mechanisms}

The abiotic factors (physico-geographical and atmospheric-climatic) are fundamental for developing of biotic process and natural responses in the ecosystems.

Physico-geographical factors are all characteristics connected to parameters specific to a given geographical area. Such physical parameters are the landscape, soil composition, the altitude, the geographical orientation, the presence or lack of water basins affecting the development of the various groups of living organisms, including insects.

Atmospheric-climatic factors include the humidity, the solar radiation and temperature, the frequency and strength of winds and storms, fires, the amount of rainfall and snowfall, etc. The drastic deviations of these characteristics lead to changes in the environment and to changes in the volume of food sources, in our caseplants.

Bioticfactors are related to the natural response. The presence and abundance of plant and animal resources are in direct correlation with climatic factors and changes. The plant species diversity and vegetation structure are nutrient base for the phytophagous entomofauna. The peculiarities in the age structure of the natural biocoenosis like the tree and shrub vegetation, the presence of enemies (predators, diseases) as well as ecological factors such as interspecific and intraspecific competition are among the main biotic factors.

Anthropogenic factors include fires, the result of human negligence or deliberate action, illegal logging, industrial and domestic pollution, uncontrolled use of pesticides which is increasingly reaching the scale of a disaster with irreversible natural consequences, deforestation - a worldwide problem reaching enormous proportions. Soil erosion is a result of deforestation and inefficient forest management, not least the replacement of forest in agricultural territories which changes also the whole entomofauna. The steady increase of mobility of people, raw materials and goods is a prerequisite for the most intensive spread of new, invasive species in certain areas, which are displacing native species and often, due to lack of natural enemies, high levels of population density are achieved (Brockerhoff et al. 2006).

\section{Cascade effect provoked by the environmental factors}

One extreme leads to the next one, which leads to a third one, resulting in a chain process, unlocked by an event in the non-living nature and reaching the final manifestations at population level, resp. individual. Climate crises and disasters resulting in damage, such as wind, snow, flooding, drought, fire are of the utmost importance. The extreme variations of certain climatic factors have a direct impact on the development and abundance of insect populations as well as organisms in general. We can confidently conclude that in every physical and climatic extreme the living nature shows a reaction. This can be manifested either in high numbers of one species or vice versa, in the mass extinction of another (Cahill et al. 2012).

A typical example in this regard is snowfall and windthrow in coniferous forests. Mass felling and death of large numbers of trees, caused by strong wind or heavy snowfall, form a favorable environment leading to a massive reproduction of some insects, for example bark beetles that find excellent conditions for their development, as well as insects feeding on decaying plant material (saproxylic species) (Lindgren \& Raffa 2013). It is argued that the atmospheric and climatic extremes, which we are witnessing, cause biological extremes that alter the environmental factors, thus directly affecting the organisms that inhabit these areas.

Many phytophagous insects (e.g. xylophagous, phylophagous, saproxylic species) accelerate their life cycles and quickly reach high numbers when an abundant food base and favorable weather conditions are available. The numbers can continue growing in the presence of sufficient food supplies and can lead to outbreaks (White \& Pickett 1985; Walker \& Willig 1999). While the nutrient base of lepidopterans is mainly the leaves of trees and shrubs, it is more diverse for beetles and includes stem, fruits, seeds, roots and decaying parts. The most important pests in the coniferous forests are scolytids that attack stressed (e.g. draught) or recently killed trees (Lindgren \& Raffa 2013). Sometimes, plantation of pine/ spruce trees on large areas contributes to bark beetle outbreaks. The concentration of a high numbers of insect individuals in turn is also an extreme process in response to the extreme conditions of environment (Pilarska et al. 2016) (Fig. 1).

The occurrence of insect outbreaks unlocks mechanisms for the emergence of natural enemies including infectious agents such as viruses, bacteria, protozoa, microsporidia, fungi and nematodes. They are involved as a response to an already triggered chain of processes that follow one after the other in a stepwise mode. The significance of pathogenic infections depend, on one hand, on the specifics determined by the life cycle of the target insect, and on the other hand on the biological characteristics of the pathogen. These specifics determine the possibilities for successful infection initiation in insect populations. The increased frequency of infection facilitates the distribution of pathogens. Infections can cause different effects on the host - from low damages to the host to a lethal effect. The virulence degree is very important for the outcome of the infection caused by the pathogen (Lacey et al. 2001).

In holometabolous insects the larvae primarily aim at rapid growth and accumulation of reserve nutrients process to reach the imaginal stage. There are many 
species in which the number of generations per year is directly related to the abundance of food and the presence of favorable climatic conditions, and this can often vary.

\section{Insect populations and their infections (pathogenic and parasitic)}

Economically important phytophagous insects are mainly from the groups of coleopterans, lepidopterans, orthopterans and some others. The search for environmentally friendly approaches to control these pests is preceded by the study of their pathogenic and parasitic complex. The development of insect overpopulations is a prerequisite for the unlocking of natural regulatory mechanisms (pathogens, parasites, parasitoids and predators), some of which cause disease in the host organisms. Some of them can reach epizootics (Fig. 1) significantly affecting the density of pests in severe pathogenicity. So here we will look at the main groups of them and some of the successfully used microbial and parasite agents in biological control.

\subsection{Viral infections}

Many insects are attacked by viruses and some of them are used as biological control agents. Insect viruses are very host specific and therefore their use is in favour for an environmentally friendly biological control. There is a diversity of insect viruses, but the more often observed are those of the families Ascoviridae, Iridoviridae, Polydnaviridae, Baculoviridae, Cypoviridae, and Entomopoxviridae (Vega \& Kaya 2012). The first viral disease called jaundice o grasserie (a nucleopolyhedrosis caused by a baculovirus) was reported in the silkworm (Bombyx mori L.) in 1524 by Vida (Ibarra \& Del Rincón-Castro 2009). In 1926, Paillot described the granuloviruses (also baculoviruses) for the first time in the larvae of cabbage butterfly Pieris brassicae L. (Rashidan et al. 2008). The first field application of a nucleopolyhedrovirus for control of the alfalfa caterpillar (Colias eurytheme Boisduval) was performed by Steinhaus and colleagues (Ibarra \& Del Rincón-Castro 2009).

The most common used viruses as viral bioinsecticides are those of Baculoviridae. Of the four genera of the family Alpha-, Beta-, Gamma-, and Deltabaculoviruses, the lepidopteran nucleopolyhedroviruses (NPV;

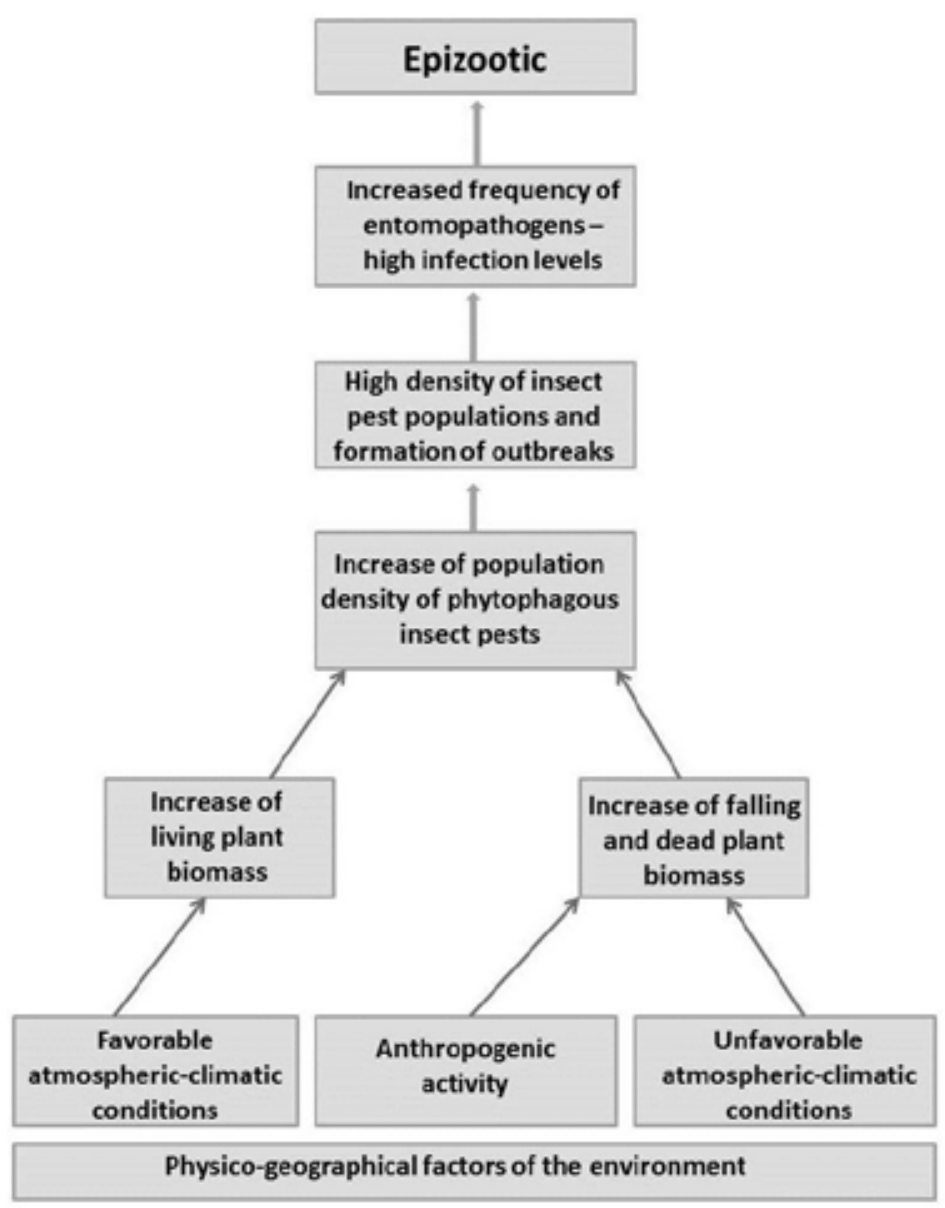

Fig. 1. Relationship between abiotic and biotic factors of nature, the insect populations, and influence of their bioagents as regulators in development of epizootic process. 
Alphabaculovirus spp.) and granuloviruses (GV; Betabaculovirus spp.) have been commercially developed (Lacey et al. 2015). The first commercial viral bioinsecticide was developed and produced in 1975 under the name Elcar by the company Sandoz. It was used to control the Heliothis/Helicoverpa complex (Ibarra \& Del Rincon-Castro 2009). The infective stage of baculoviruses has circular double stranded DNA within rod shaped nucleocapsids that are encased within occlusion bodies of crystalline protein. Baculoviruses play important role in controlling some globally important lepidopteran pest species such as Helicoverpa spp. (Rowley et al. 2011) and Spodoptera spp. Recently, in China, nine baculoviris products are commercially available and there are at Chinese manufacturers of Helicoverpa armigera NPV (HearNPV) and several of Spodoptera litura NPV (SpltNPV), Autographa californica NPV (AucaMNPV), Plutella xylostella GV (PlxyGV) and Spodoptera exigua NPV (SeMNPV) (Lacey et al. 2015). In Brazil there is a well-established program for production and use of Anticarsia gemmatalis NPV (AngeMNPV) for control of velvet bean caterpillar (Anticarsia gemmatalis Hübner) on soybean. One of the most widely used commercially developed viruses is the codling moth, Cydia pomonella granulovirus (CpGV) which is used recently worldwide. The use of baculoviruses in forest insect pest control in North America and Europe is still limited. Lymantria dispar multicapsid nuclear polyhedrosis virus (LdMNPV) is very often the main reason of collapse of natural outbreaks of this important forest pest. It is artificially produced by the U.S. Forest Service and used as biological insecticide under the registered name Gypchek (D'Amico et al. 2012). Commercial production of sawfly Neodiprion abietis Harris is also under development (Lacey et al. 2015).

\subsection{Bacterial infections}

Bacteria of genus Bacillus (especially Bacillus thuringiensis Berliner ) are the most frequently used bacteria for controlling insect pest populations. They are rod-shaped and chain-forming. Under adverse atmospheric conditions they produce spores that, in some species, form parasporal bodies. The spore forming bacterium $B$. thuringiensis Berliner was isolated in 1901 by Shigetane Ishiwata from the larvae of the silkworm Bombyx mori (Ishiwata 1901). It was later isolated from the Mediterranean flour moth Ephestia kuehniella Zeller from Germany by Ernst Berliner (Milner 1994). B. thuringiensis $(B t)$ has over 90 subspecies. The bacterium kills through its specific toxins, of which there are over 30 types, specific to different groups of insects. Traditionally, B. thuringiensis strains have been classified into pathological types with activity against various lepidopterans, coleopterans and dipterans. $B t$ strains are isolated as effective agents against insect orders Blattaria, Hemiptera,
Hymenoptera, Isoptera, and Orthoptera. The bacterial biopesticides are currently the largest part of the global microbial pesticide market. There are over 225 bacterial pesticides. Currently, the most important are pesticides based on B. thuringiensis $-80 \%$ of all pesticides. Interestingly, insects can tolerate $B t$ toxins, but genetically modified strains are being developed that are effective for biological control. The host specific pathogenicity of different $B t$ strains is encoded by genes that distinguish host recognition by the pathogen.

Another species of entomopathogenic bacteria, Paenibacillus larvae White, is an important pathogen of the European honeybees, Apis mellifera L. and also causes so-called milky disease in the larvae of the Japanese beetle Popilliajaponica Newman. The first bacterial pesticide was based on Paenibacillus popiliae Dutky. It attacks the Japanese beetle $P$. japonica. Other important gram negative bacterial species are from Enterobacteriaceae, species of genus Yersinia, Pseudomonas, Rikettsiella. Present studies consider Gram-negative Chromobaterium, Yersinia, Pseudomonas as potential regulatory agents. Two species of Photorhabdus and Xenorhabdus use entomopathogenic nematodes (genus Steinernema) as vectors to enter the insects. Wolbachia is an example of a reproductive parasite. Some Wolbachia strains are capable of turning genetically male animals into functional females - this is the case with the Asian butterfly Ostriniafurnacalis Guenée. The characteristics of Wolbachia determine its high potential as a means of controlling arthropod-borne diseases.

\subsection{Fungal infections}

Entomopathogenic fungi are a group of phylogenetically diverse heterotrophic microorganisms that can act as insect parasites and can utilize insect tissues as a nutritional source to develop their life cycle. At present, there are estimated over 750 recognized species of insect-pathogenic fungi in over 100 genera (Vega et al. 2012). However, based on the number of cryptic species revealed by recent molecular studies (e.g. Rehner 2009; Rehner et al. 2011), it is evident that this number of species is underestimated. A majority of economically important species belongs to the phyla Ascomycota (order Hypocreales) and Entomophthoromycota (orders Entomophthorales and Neozygitales). While hypocrealean fungi are more general insect pathogens with a constant but low prevalence level in insect populations, Entomophthorales and Neozygitales are relatively host specific and prone to epizootic outbreaks. The latter two groups of fungi are well known for causing dramatic epizootics in host populations. In particular, Entomophaga maimaiga Humber, Shimazu et R. S. Soper (Entomophthoromycota: Entomophthorales) regularly causes epizooticsin populations of gypsymoth caterpillars in the United States (Hajek 1999). Entomopathogenic 
fungi are considered excellent candidates for biological control of various insect pests in agriculture and forestry (Charnley \& Collins 2007; Roy et al. 2010; Patil 2011; Humber 2016). Hypocrealean fungi such as Beauveria spp., Isaria spp., Metarhizium spp., and Lecanicillium spp. can be easily mass-produced for application as mycoinsecticides and numerous commercial formulations for inoculative and inundative biocontrol are available (de Faria \& Wraight 2007; Ravensberg 2011; Reddy et al. 2013; Lacey et al. 2015). On the other hand, a mass production of entomophthoralean fungi is not possible for a majority of species, due mostly to difficulties with in vitro growth and inoculum stability, therefore these fungi, such as E. maimaiga, are suitable for strategies of classical biological control (Hajek 1999).

In a general view, the pathogenesis by entomopathogenic fungi starts with attaching of mitosporic spores (conidia) to the external body surface of insects. Under suitable temperature and humidity conditions, the conidia germinate on the host cuticle and form germ tubes that penetrate through the insect integument to colonize the hosts' body cavity (haemocoel) (St. Leger 1993; Hajek \& St. Leger 1994). The fungi proliferate in the haemocoel, usually as walled hyphae/hyphalbodies or in the form of wall-less protoplasts. During this process, which involve the production of secondary metabolites, the internal organs of the hosts are gradually degraded and ultimately the insects die. Then the fungi grow out of the cadavers, produce conidia in suitable conditions and disseminate in the environment. High humidity is usually prerequisite for conidiogenesis. Conidia are short-lived (up to several days) propagules that are responsible for horizontal transmission of disease in populations. Several species can also form durable, but non-infective, resting spores inside host bodies. They are capable to persist a prolonged period (several years) of adverse conditions in the environment and produce infective conidia when environmental conditions become again favourable (Hajek \& St. Leger 1994; Hajek 1999; Vega et al. 2012).

The introduction of entomopathogenic fungus $E$. maimaiga from Asia to the United States during the 20th century is an excellent example of successful story for classical microbial control of forest pests. Entomophaga maimaiga is strictly host-specific and the most important entomopathogen of gypsy moth, Lymantria dispar L. (Lepidoptera: Erebidae) (Hajek et al. 1996; Hajek 1999). The successful introduction of E. maimaigainto the North America inspired Bulgarian insect pathologists, and in 1999 the fungus was introduced into Bulgaria (Pilarska et al. 2000). Surveys conducted at release sites during subsequent years confirmed successful transmission of the pathogen to the Bulgarian populations of $L$. dispar. The first epizootics by this fungus in gypsy moth populations were observed in 2005 (Pilarska et al. 2006 2013; Georgiev et al. 2013). Since 2011, the fungus has been recorded in several countries of Central and Southeastern Europe (Kereselidze et al. 2011; Georgiev et al. 2012; Tabaković-Tošić et al. 2012; Hrašovec et al. 2013; Csóka et al. 2014; Zúbrik et al. 2014; 2016; Hoch et al. 2019).

Hypocrealean entomopathogenic fungi are among important natural mortality factors of forest pests worldwide. Although natural epizootics by these fungi are not usual in host populations, numerous laboratory experiments have already shown their high efficacy against variety of insect pests. In Europe, this group of fungi has been widely studied in outbreaks of the most destructivepest of coniferforests, theEurasian sprucebark beetle, Ips typographus [L.] (Coleoptera: Curculionidae). The bark beetle attacks stressed and dying spruce trees (Picea abies [L.] H. Karst.), but it is capable of destroying healthy trees as soon as pest population exceeds critical numbers (Wermelinger 2004). Windstorms and severe drought periods are recognized the key triggers for a gradation of I. typographus (Økland \& Bjørnstad 2006). Several species of hypocrealean entomopathogenic fungi can be identified from field-collected bark beetles and Beauveria species are usually predominant ones (Landa et al. 2001; Kreutz et al. 2004a; Wegensteiner 2007; Draganova et al. 2010, 2017; Mudrončeková et al. 2013; Wegensteiner et al. 2015a; Wegensteiner et al. 2015b; Barta et al. 2018a). For example, in Slovakia a majority (89\%) of infected I. typographus adults collected in forests were killed with Beauveria and only a minor part was infected with Isaria (8\%) or Lecanicillium (3\%) (Barta et al. 2018a). Out of the Beauveria genus, B. bassiana (Bals.-Criv.) Vuill. is the most common species identified in bark beetle populations, but B. pseudobassiana S. A. Rehner et R. A. Humber, B. caledonica Bissett et Widden and B. brongniartii (Sacc.) Petch can also be detected (Takov et al. 2012; Barta et al. 2018a). Pathogenicity of Isaria species against bark beetles in laboratory bioassays is significantly lower when compared with $B$. bassiana (e.g. Markova 2000; Draganova et al. 2007; Herrmann \& Wegensteiner 2010). B. bassiana is therefore tested against bark beetles in laboratory and field trials applying different approaches of inoculum introduction into the bark beetle environment. Generally, results of laboratory assays suggest its high potential for effective biocontrol, however field applications do not demonstrate adequate efficacy. This indicates a need for selecting highly effective strains and improvement of inoculum formulation or application (Hallet et al. 1994; Vaupel and Zimmermann 1996; Kreutz et al. 2004a, 2004b; Jakuš \& Blaženec 2011; Vakula et al. 2012; Mudrončeková et al. 2013; Grodzki \& Kosibowicz 2015). Recently, a highlyvirulent $B$. bassiana strain has been selected against the bark beetle in Slovakia (Barta et al. 2018a, 2018b) and its field efficacy currently undergo a series of experiments. 


\subsection{Microsporidian infections}

Microsporidia are obligate, intracellular pathogens which cause infections of all animal taxa. They belong to Opisthosporidia, a sister group of the true Fungi (Karpov et al. 2014) and are mostly found in insect hosts. There are more than 90 insect species recorded as type hosts of different microsporidian genera (Solter et al. 2012). Generally, entomopathogenic microsporidia are known to produce chronic effects in their hosts leading to low or moderate mortality and that there are often no external signs of infection (Yaman 2020). However they can reduce the reproduction and feeding of their hosts, which cause a decrease of the insect populations. Thus microsporidia are also good candidates for use as classical biological control agents (Hajek \& Delalibera 2010; Yaman et al. 2019).

So far, there is only one commercial product available, based on Paranosema (Nosema) locustae Canning, for control of grasshoppers and crickets (Bjornson \& Oi 2014). A good example for research on the possibilities for using microsporidia as classical biological control agents is the study on the microsporidia of the gypsy moth, L. dispar. A group of insect pathologists from Europe (Bulgaria, Germany, Austria, Slovakia, Czech Republic) and the United States started to screen $L$. dispar populations in Europe. As a result of their cooperation, four species of microsporidia were recovered from European and Bulgarian populations of the gypsy moth (Pilarska et al. 1998; Solter et al. 2000; Vavra et al. 2006; Pilarska et al. 2010). The life history, morphology, host tissue specificity, virulence and persistence, and biology of several of these microsporidia have been extensively studied to elucidate interactions with the host and to facilitate decisions regarding use in classical biological control programs (Solter at al. 2000, 2002; Goertz et al. 2004; Vavra et al. 2006; Hoch et al. 2008; Pilarska et al. 2010). A release of two microsporidian species Vairimorpha disparis Timofejeva and Nosema lymantriae Weiser isolated from Bulgaria was conducted in 2007 and 2008 in two Bulgarian gypsy moth populations and it was shown that $N$. lymantriae persisted in the test population within three years (Pilarska et al. 2010).

\subsection{Protozoan infections}

Protozoans exhibit a full range of relationships with insects - from mutualism to parasitism. Apicomplexa (Sporozoa) is the main phylum whose representatives develop intracellularly. Most of the eugregarines are commensal while others, such as neogregarins and coccidia are highly pathogenic. Their host specificity varies greatly. There are several obvious outward signs of symptoms, which are typically chronic and occult, with no apparent discoloration or appearance on the body surface of the species affected. Insect larvae that are severely infected with neogregarins and coccidia show swelling and sluggishness in their movements. These signs and behavior can easily be confused with the process of pupation.

Amoebae, for example, are eukaryotes that are in the Amebozoa. The presence of pseudopods and cytoplasm movement during locomotion and feeding is a characteristic feature of the group. Postmortem diagnosis, after the death caused by protozoan infections, is easy. Because of their larger size they are clearly visible under a light microscope and have a characteristic shape and morphology. Over six species of amoebae (mainly the genus Malamoeba) of three genera are found mainly in grasshoppers, beetles (bark beetles and other curculionids), bees and apterygots.

The eugregarines are larger-sized unicellular obligate parasites, mainly found in the gut of dipterans, beetles, cockroaches, odonates and orthopterans, mainly of the genera Gregarina, Ascogregarina, Haplorhynchus. Several reviews (Brooks 1988; Boucias \& Pendland 1998; Vega \& Kaya 2012) concluded that eugregarins are symbionts that fluctuate between mutualism, commensalism and parasitism depending on a number of factors. Some of the eugregarines - Aseptata, such as Ascogregarina, would have potential as biological agents. Studies have shown that there are geographic variations in pathogenicity, for example, some strains of Ascogregarina culicis Ross are pathogenic to Aedes aegypti $\mathrm{L}$. (Sulaiman 1992).

Neogregarines, mostly known as schizogregarins, are found almost exclusively in insects. They form pellicle-coated movable sporozoites and merozoites that are characteristic of the type. Oocysts of the neogregarines that form gametocysts are typically ovate or lemonshaped. The main genera are Matessia and Farinocystis, all of which infect pests, feeding on fruits, seeds and nuts. The genus Cauleryella infects dipterans - mainly mosquitoes. Ophryocystis is another genus mainly found in the Malpighian tubes of beetles.

Some coccidia, such as Adelina, are found in Coleoptera, Lepidoptera, Orthoptera, Diptera, Embioptera and Blattaria. Infection occurs via food, with some species inhabiting the gut. It begins by penetrating the ingestion of oocysts and sporocysts into suitable hosts. Coccidia are mainly vertebrate parasites, with less than $1 \%$ infecting insects, and in most cases the insects are vectors for the coccidia to other hosts (Lange \& Lord 2012).

\subsection{Nematode infections}

Nematodes occur often as parasites or are associated mainly with forest coleopterans (Curculionidae, Cerambycidae and other families of the order). Bark beetles are one of the xylophagous insects causing damages in the forest ecosystems and are known as hosts or vectors of nematodes. Among with the nematodes there are many phoretic or mutualistic species that are associated with 
bark beetles and are common in their galleries (Rühm 1956; Massey 1974). The phoretic nematodes use bark beetles as a means of transport to reach new food plants and their tissues. Very often, phoretic nematode species can enter the haemocoel and cause an enlarged fat body and undeveloped gonads compared to uninfected individuals.

However, for controling populations of beetles, only the parasitic nematodes are of importance. Most important is the role of the Tylenchida (Siddiqui 2000) and Aphelenchida (Poinar 1975) groups. The genera Cryptaphelenchus, Parasitylenchus and Contortylenchus are primarily found in the bodies of the beetles - in the Malpighian tubules or actively entering the larvae through the oral or anal opening or through the cuticle of the pupae. Female nematodes of the genus Contortylenchus can penetrate the beetles directly through the integument, although penetration through the oral and anal openings with subsequent intestinal penetration into the haemocoel is also possible. Once there, the females can be found in the thorax and abdomen. The infected beetle larvae continue to develop, pupate and become adults. There, the female nematodes continue their development with the formation of eggs. But usually eggs do not hatch until mature beetles develop. After four larval instars of nematodes taking place in adult beetles, they migrate to the galleries with the faecal mass of the host, where they reach maturity and the males and females mate. The males then quickly die and the fertilized females reenter the bark beetle larvae and pupae to start the cycle again (Kaya 1984). Wegensteiner et al. (2015b) listed more than 20 species of bark beetles that are associated in one or another degree with nematodes, emphasizing that genera such as Parasitylenchus, Sulphuretylenchus and Neoparasitylenchus are capable of killing bark beetles under certain conditions. The number of individuals in a single host can reach hundreds. Classically entomopathogenic nematodes for the control of bark beetles under experimental conditions are those of the family Steinernematidae and Heterorhabditidae (Gaugler \& Kaya 1990). In natural populations of hosts, however, they have not been found.

The nematodes related with the insects in the forest are devided into two groups: typical parasites and species associated with the insects to varying degrees. The latter can develop different types of relationships leading to simple phoresis or passage through the intestine or haemocoel of the insect, and can damage insect health. One group of the nematodes in the forest communities inhabits the soil, others are phytoparasitic, developing in the wood, and the third group develops in rotting and decaying parts of dead trees, where certain fungal species have previously developed. There are also typical parasites found in the bodies of some forest insects. Very often, insects are vectors for nematodes, spreading them to forest areas.
A typical example for phoresis is the transportation of the nematodes of genus Bursaphelenchus (Parasitaphelenchidae) by the beetles of familes Cerambycidae and Curculionidae. Nematodes are ofter transported below the elytra of the beetles or on the surface of the body and their legs. Many nematode species develop in insect galleries of some bark beetles which cultivate fungi to feed the larval stages (Wang et al. 2013).

The nematodes have chemoreceptors, actively search for their host and enter it as invasive larvae. High rates of infection are often reported, with values reaching $90-100 \%$ for a single species of host, and the intensity of infection can reach 7500 nematode larvae and eggs in the haemocoel of one individual (Kaya 1984). In the case of severe invasion, reduced fertility and sterility of bark beetles are often reported: developmental delay, reduction in the size of the fat body and infestation of the Malpighian tubules and the trachea (Wegensteiner 2004). Damage can range from reduced fertility to death of the host, mostly caused by species of Rhabditida order and some Tylenchida order. The parasitic nematodes of the beetles in most cases do not kill their hosts immediately, even when more than one nematode enters the haemocoel.

\section{Basic aspects of the epizootiological process}

For the prognosis of epizootic dynamics, the characteristics associated with the particular insect host, the peculiarities of the pathogen and the dynamics of the environment are considered in order to construct models of the epizootic process. Models are theoretical, empirical, and simulative (Onstad \& Carruthers 1990).

Different models set out certain temporal and spatial characteristics related to host dynamics. According to some authors (Bailey 1975) a homogeneous pathogen transmission mode is assumed, while others (Getz \& Pickering 1983) replace absolute density with the proportion of sensitive specimens, such as those transmitted sexually, where the density threshold does not exist.

In turn, the host population may be homogeneous or heterogeneous. Spatial distribution is simulated by different models. For example, one model simulates mortality caused by NPV Malacosoma pluviale (Welington et al. 1975), dividing hosts into eight different classes - from pathogen-free to highly infected nests, with vertical transmission based on fixed rates that depend on the degree of disease in the colony. Horizontal transmission is dynamically modeled and evaluated at eight daily intervals. According to the authors, the progression of the disease is based on spatial proximity to other diseased colonies for spatial network formation, host density and age, and quality characteristics such as genetics and insect stress. Comprehensive modeling 
of NPV in L. dispar populations (Doane 1976) had been performed to study the effects of virulence and virus transmission during epizootic development. Models were based on several features: larval body size, intestinal loading of viral particles, inoculum spread into the environment, natural breakdown of the virus, and amount of infected leaf mass consumed by the larvae (Etter1981; Valenttine 1981; Valentine \& Podgwaite 1982). The model predicted density based on baseline density and terminal morbidity levels. The results showed that simulated increases in virus mortality could lead to an overall decrease in $L$. dispar mortality by reducing the effects of the virus.

Anderson \& May (1981) analyzed the conditions necessary for host regulation and created models describing the pathogen-host interaction. They discuss eight different models, all of which included a number of parameters: horizontal and vertical dynamics of pathogen transmission, host sensitivity, frequency of reproduction and mortality, presence of a latent period, fertility reduction, fertility-related, mortality dependent on the density and presence of infectious agents (spores) in the medium. The authors noted that all these processes (factors) are important for the dynamics of the disease, except for the virulence caused by stress. They concluded that pathogens often regulate their hosts, suggesting that the infectious stages would be homogeneously distributed in the environment and would continuously mix with the susceptible host population. The conclusion was that if a highly virulent pathogen has produced a large number of persistent free-living stages, then stable cyclic changes in host density were likely to occur. According to epidemiological theory, the density threshold is equivalent to herd immunity (collective immunity) (Kermack \& McKendrick 1927; Bailey 1975). Anderson \& May (1981), for their part, considered that the host threshold level was sufficient to explain the high density and epidemic outbreaks of the disease, and also concluded that when host abundance fell below threshold levels, the pathogen could be, periodically or episodically, maintained at intervals by producing freeliving infectious stages transmitted vertically or by occult infection (Regniere 1984).

According to Onstad et al. (1990), who examined the system Ostrinia nubilalis Hübner - Nosema pyrausta Paillot the threshold changed with the original spread of disease changes, indicating that both the prevalence and the density of susceptible individuals had to be measured in order to predict the future dynamics. In theoretical models, interaction between infected and susceptible hosts is considered to be the determining factor for transmission of infection. The authors assumed that the contamination degree was directly proportional to the densities of the two types of hosts. This is based on the belief that the population is homogeneous and in all respects constantly mixed with the infected individuals of the population, which is crucial for the development and spread of the disease, as well as for their specific interactions in a changing environment. Pathogens that require alternative hosts infect multiple species or produce different spores under different environmental conditions, and they represent an example of behavior that is difficult to predict (Onstad \& Carruthers 1990).

\section{Conclusion}

The relationship between the density of insect populations and their pathogens is natural (or prospective), since the pathogenic process appears to be regulatory for the increased numbers of its hosts. On the other hand, the pathogen-host relationship must be considered at the species level for both groups of organisms. For the host, the particularities of the lifestyle (whether hidden or not, whether in groups or not), the type of food resource they use (leaves, stem, roots, fruits, seeds, decomposing plant and tree organic matter), the degree of contact between individuals and their duration over time, the mode of reproduction (monogamy, polygamy), the number of generations per year, etc. are essential.

For pathogens, most important is the access to the host insect, their virulence and pathogenicity, the mode of infection and transmission (oral-fecal route, surface contact, active parasite entry, transovarial transmission). Maintaining foci of infection in insect populations is also important for a successful spread in the host population.

Fungal pathogens have the greatest potential because of their high virulence and pathogenicity, due to toxic compounds produced. At the same time, they have an effective and rapid spread (through spores, airborne transfer) and an easy way to infect (with superficial contact through the insect cuticle). Infections caused by protozoa, microsporidia and nematodes lead to a chronic process in their host and there is no effective control of the pest host density during mass outbreaks. Often these pathogens are not host specific. A key problem remains to find host-specific pathogens that do not affect non-target insect groups. This is a major task for researchers in the field of biological control.

Since we cannot easily control environmental and anthropogenic factors and thus population growth of insects, the main task should be directed to the efficientmanagement of natural resources, which includes good expert forecasting of the forthcoming processes of phenomena and their impact in the ecosystems.

In our opinion, when an insect calamity occurrs (due to increased nutrient base and depending on the life cycle of a host, environmental conditions and virulence of a particular pathogen), three main development scenarios are possible:

1. Death of a small number of infected individuals and attenuation of the infection process.

2. Occurrence of a number of individual infection foci (groups of infected individuals) and death of indi- 
viduals in them, but without major damage to the host population.

3. Diffuse developing spread of the pathogen with mass infection of individuals and subsequent development of an epizootic with the presence of high mortality in the population of host insects.

\section{References}

Anderson, R. M., May, R. M., 1981: The population dynamics of microparasites and their invertebrate hosts. Philosophical Transactions of the Roayl Society, Ser. B, 291:451-524.

Bailey, N. T. J., 1975: The Mathematical theory of infectious diseases and its applications. London, Griffin.

Barta, M., Kautmanová, I., Čičková, H., Ferenčík, J., Florián, Š., Novotný, J. et al., 2018a: Hypocrealean fungi associated with populations of Ips typographus in West Carpathians and selection of local Beauveria strains for effective bark beetle control. Biologia, 73:53-65.

Barta, M., Kautmanová, I., Čičková, H., Ferenčík, J., Florián, Š., Novotný, J. et al., 2018b: The potential of Beauveria bassiana inoculum formulated into a polymeric matrix for a microbial control of spruce bark beetle. Biocontrol Science and Technology, 28:718-735.

Bjornson, S., Oi, D., 2014: Microsporidia biological control agents and pathogens of beneficial insects. In: Weiss L., Becnel J. (eds.): Microsporidia: Pathogens of Opportunity: First Edition. John Wiley \& Sons, p. 635-670.

Boucias, D. G., Pendland, J. C., 1998: Principles of insect pathology. Kluwer Academic Publisher, Dordrecht, The Netherlands, $537 \mathrm{p}$.

Brockerhoff, E. G., Liebhold A. M., Jactel, H., 2006: The ecology of forest insect invasions and advances in their management. Canadian Journal of Forest Research, 36, 2:263-268.

Brooks, W. M., 1988: Entomogenous Protozoa. In: Ignoffo C.M. (ed.): Handbook of Naturally Occurring Pesticides. CRC Press, Boca Raton. Florida, p. $1-149$.

Burney, D. A., Flannery, T. F., 2005: Fifty millennia of catastrophic extinctions after human contact. Trends in Ecology and Evolution, 20:395-401.

Cahill, A. E., Aiello-Lammens, M. E., Fisher-Reid, M. C., Hua, X., Karanewsky, C. J.,Yeong Ryu, H. et al., 2012: How does climatechange cause extinction? Proceeding of the Royal Societes of Biological Sciences, 280:2012.1890.

Charnley, A., Collins, S., 2007: Entomopathogenic fungi and their role in pest control. In: Kubisek, C., Druzhinina, I. (eds.): The Mycota IV, Environmental and Microbial Relationships, Springer Berlin Heidelberg USA, p. 159-187.
Csóka, G. Y., Hirka, A., Szőcs, L., Hajek, A. E., 2014: First occurrence of the entomopathogenic fungus, Entomophaga maimaiga Humber, Shimazu and Soper (Entomophthorales: Entomophthoraceae) in Hungarian gypsy moth (Lymantria dispar) populations. Növényvédelem, 50:257-262.

de Faria, M. R., Wraight, S. P., 2007: Mycoinsecticides and mycoacaricides: a comprehensive list with worldwide coverage and international classification of formulation types. Biological Control, 43:237-256.

D’Amico, V., Slavicek, J., Podgwaite, J., Thorpe, K., Webb, R., Fuester, R. et al., 2008: An indepth look at new viral strains for use in Gypchek. In: Gottschalk, Kurt W. (ed.): Proceedings, 18th U.S. Department of Agriculture interagency research forum on gypsy moth and other invasive species 2007. Gen. Tech. Rep. NRS-P-28. Newtown Square, PA: U.S. Department of Agriculture, Forest Service, Northern Research Station: 16.

Doane, C. C., 1976: Ecology of pathogens of the gypsy moth. In:Anderson, J. F., Kaya, H. K. (eds.): Perspectives in Forest Entomology, New York, Academic, p. 285-293.

Draganova, S., Doychev, D., Pilarska, D., Takov, D. 2017: Bioassays with entomopathogenic fungi against some xylophagous insects in Bulgaria Laboratory and Field Experiments. Acta Zoologica Bulgarica, 69:411-419.

Draganova, S., Takov, D., Doychev D., 2010: Naturally occurring entomopathogenic fungi on three bark beetle species (Coleoptera: Curculionidae) in Bulgaria. Pestic Phytomedicine (Belgrade), 25:59-63.

Draganova, S., Takov, D., Doychev, D., 2007: Bioassays with isolates of Beauveria bassiana (Bals.) Vuill. and Paecilomyces farinosus (Holm.) Brown \& Smith against Ips sexdentatus Boerner and Ips acuminatus Gyll. (Coleoptera: Scolytidae). Plant Science, 44:24-28.

Etter, D. O., 1981: Pest management systems of development. In: Doane, C. C., McManus M. L. (eds.): The Gypsy Moth: Research Toward Integrated Pest Management. USDA-APHIS Tech. Bull. 1584, p. 716-725.

Gaugler, R., Kaya, H., 1990: Entomopathogenic Nematodes in Biological Control. CRC Press. 365 p.

Georgiev, G., Mirchev, P., Georgieva, M., Rossnev, B., Petkov, P., Matova, M., Kitanova, S., 2012: First record of entomopathogenic fungus Entomophaga maimaiga Humber, Shimazu and Soper (Entomophthorales: Entomophthoraceae) in Lymantria dispar (Linnaeus) (Lepidoptera: Lymantriidae) in Turkey. Acta Zoologica Bulgarica, 64:123-127.

Georgiev, G., Mirchev, P., Rossnev, B., Petkov, P., Georgieva, M., Pilarska, D. et al., 2013: Potential of Entomophaga maimaiga for suppressing Lymantria dispar outbreaks in Bulgaria. Proceedings of the Bulgarian Academy of Sciences, 66:1025-1032. 
Getz, W. M., Pickering, J., 1983: Epidemic models: thresholds and population regulation. The American Naturalist, 121:892-898.

Goertz, D., Pilarska, D., Kereselidze, M., Solter, L., Linde, A., 2004: Studies on the impact of two Nosema isolates from Bulgaria on the gypsy moth (Lymantria dispar L.). Journal of Invertebrate Pathology, 87:105-113.

Grodzki, W, Kosibowicz, M., 2015: An attempt to use the fungus Beauveria bassiana (Bals.) Vuill. in forest protection against the bark beetle Ips typographus (L.) in the field. Forest Research Papers, 76: 5-17.

Hajek, A. E., 1999: Pathology and epizootiology of Entomophaga maimaiga infections in forest lepidoptera. Microbiology and Molecular Biology Reviews, 63:814-835.

Hajek, A. E., Butler, L., Walsh, S. R. A., Silver, J. C., Hain, F. P., Hastings, F. L. et al., 1996: Host range of the gypsy moth (Lepidoptera: Lymantriidae) pathogen Entomophaga maimaiga (Zygomycetes: Entomophthorales) in the field versus laboratory. Environmental Entomology, 25:709-721.

Hajek, A. E., Delalibera, I. Jr., 2010: Fungal pathogens as classical biological control agents against arthropods. BioControl, 55:147-158.

Hajek, A. E., St. Leger, R., 1994. Interactions between fungal pathogens and insect hosts. Annual Review of Entomology, 39:293-322.

Hallet, S., Gregoire J. C., Coremans-Pelseneer, J., 1994: Prospects in the use of the entomopathogenous fungus Beauveria bassiana (Bals.) Vuill. (Deuteromycetes: Hyphomycetes) to control the spruce bark beetle Ips typographus L. (Coleoptera: Scolytidae). Mededelingen van de Faculteit Landbouwwetenschappen, Rijksuniversiteit Gent, 59:379-383.

Herrmann, F., Wegensteiner, R., 2010: Infecting Ips typographus (Coleoptera, Curculionidae) with Beauveria bassiana, Metarhizium anisopliae or Isaria fumosorosea (Ascomycota). IOBC/wprs Bulletin, 66:209-212.

Hoch, G., D’Amigo, V., Solter, L., Zúbrik, M., McManus, M., 2008: Quantifying horizontal transmission of Nosemalymantriae, a microsporidian pathogen of the gypsy moth, Lymantria dispar (Lep., Lymantriidae) in field cage studies. Journal of Invertebrate Pathology, 2:146-150.

Hoch, G., Pilarska, D., Georgieva, M., Georgiev, G., Mirchev, P., Schafellner, C., 2019: Erstnachweis des insektenpathogenen Pilzes Entomophaga maimaiga in Populationen des Schwammspinners in Österreich. Forstschutz Aktuell, 66:1-5.

Hrašovec, B., Pernek, M., Lukić, I., Milotić, M., Diminić, D., Franjević, M. et al., 2013: First record of the pathogenic fungus Entomophaga maimaiga Humber, Shimazu, and Soper (Entomophthorales: Entomophthoraceae) within an outbreak populations of Lymantria dispar (Lepidoptera: Erebidae) in Croatia. Periodicum Biologorum, 115:379-383.
Humber, R., 2016: Seeking stability for research and applied uses of entomopathogenic fungi as biological control agents. Journal of Asia-Pacific Entomology, 19:1019-1025.

Ibarra, J. E., Del Rincón-Castro, C. M., 2009: Insect viruses diversity, biology, and use as bioinsecticides. In: Del Claro, K., Oliveira, P. S., Gray, V. R (eds.): Tropical Biology and Conservation Management, Volume 7: Phytopathology and Entomology, EOLSS Publications, 304 p.

Ishiwata, S., 1901: On a new type of severe flacherie (sotto disease). Dainihon Sansi Kaiho 114:1-5.

Jakuš, R., Blaženec, M., 2011: Treatment of bark beetle attacked trees with entomopathogenic fungus Beauveria bassiana (Balsamo) Vuillemin. Folia Forest Polonica, ser A, 53:150-155.

Karpov, S.A., Mamkaeva, M.A., Aleoshin, V.V., Nassonova, E., Lilje, O., Gleason, F. H., 2014: Morphology, phylogeny, and ecology of the aphelids (Aphelidea, Opisthokonta) and proposal for the new superphylum Opisthosporidia Frontiers in Microbiology, 5: Article 112.

Kaya, H. K., 1984: Nematode parasites of bark beetles,. In: W. R. Nickle (ed.): Plant and Insect Nematodes, Marcel Dekker, New York, p. 727-754.

Kereselidze, M., Pilarska, D., Hajek, A., Jensen, A. B., Linde, A., 2011: First record of Entomophaga maimaiga Humber, Shimazu \& Soper (Entomophthorales: Entomophthoraceae) in Georgia. Biocontrol Science and Technology, 21:1375-1380.

Kermack, W.O., McKendrick,A.G., 1927:Acontribution to the mathematical theory of epidemics. Proceedings of Royal Society of London, Ser. A, 115:700-721.

Kreutz, J., Vaupel, O., Zimmermann, G., 2004a: Efficacy of Beauveria bassiana (Bals.) Vuill. against the spruce bark beetle, Ips typographus L., in the laboratory under various conditions. Journal of Applied Entomology, 128:384-389.

Kreutz, J., Zimmermann, G., Vaupel, O., 2004b: Horizontal transmission of the entomopathogenic fungus Beauveria bassiana among the spruce bark beetle, Ips typographus (Col., Scolytidae) in the laboratory and under field conditions. Biocontrol Science and Technology, 14: 837-848.

Lacey, L. A, Frutos, R., Kaya, H. K., Vail, P., 2001: Insect Pathogens as Biological Control Agents: Do They Have a Future? Insect Pathogens as Biological Control Agents: Do They Have a Future? Biological Control, 21:230-248.

Lacey, L. A., Grzywacz, D., Shapiro-Ilan, D. I., Frutos, R., Brownbridge, M., Goettel, M. S., 2015: Insect pathogens as biological control agents: back to the future. Journal of Invertebrate Pathology, 132:1-41.

Landa, Z., Horňák, P., Osborne, L.S., Nováková, A., Bursová, E., 2001: Entomogenous fungi associated with spruce bark beetle Ips typographus L. (Coleoptera, Scolytidae) in the Bohemian Forest. Silva Gabreta, 6:259-272. 
Lange, C., Lord, J. C., 2012: Protistan entomopathoges. In: Vega, F., Kaya, H. (eds.). Insect Pathology, p. 367-394.

Liebhold, A. M., 2012: Forest pest management in a changing world. International Journal of Pest Management, 58, 3:289-295.

Lindgren, B. S., Raffa, K. F., 2013: Evolution of tree killing in bark beetles (Coleoptera: Curculionidae): trade-offs betweenthe maddening crowds and a sticky situation. Canadian Entomolgis, 145:471-495.

Markova, G., 2000: Pathogenicity of several entomogenous fungi to some of the most serious forest insect pests in Europe. IOBC/wprs Bulletin, 23:231-239.

Massey, C. L., 1974: Biology and taxonomy of nematode parasites and associates of bark beetles in the United States. USDA Agriculture Handbook, 446:1-238.

Milner, R., 1994: History of Bacillus thuringiensis. Agriculture, Ecosystems and Environment, 49:9-13.

Mudrončeková, S., Mazáň, M., Nemčovič, M., Šalamon, I., 2013: Entomopathogenic fungus species Beauveria bassiana (Bals.) and Metarhizium anisopliae (Metsch.) used as mycoinsecticide effective in biological control of Ips typographus (L.). Journal of Microbiology, Biotechnology and Food Science, 2:2469-2472.

Økland, B., Bjørnstad, O. N., 2006: A resource-depletion model of forest insect outbreaks. Ecology, 87:283290.

Onstad, D. W., Carruthers, I. R., 1990: Epizootiological models of insect diseases. Annual Review of Entomology, 35:399-419.

Onstad, D. W., Maddox, J.V., Cox, D. J., Kornkven, E.A., 1990: Spatial and temporal dynamics of animals and the host-density threshold in epizootiology. Journal of Invertebrate Pathology, 55:76-84.

Patil, S., 2011: Development of entomopathogenic fungi based biopesticide technology. Lambert Academic, $188 \mathrm{p}$.

Pilarska, D., Georgiev, G., Golemansky, V., Pilarski, P., Mirchev, P., Georgieva, M.et al., 2016:Entomophaga maimaiga (Entomophtorales, Entomophtoraceae) in Balkan peninsula - an overview. Silva Balcanica, 17:31-40.

Pilarska, D., Linde, A., Pilarski, P., Georgiev, G., Takov, D., Solter, L., 2010: Release of Nosema lymantriae, Vairimorpha disparis and Entomophaga maimaiga for classical and augmentative biological control of gypsy moth in Bulgaria and the United states. 43rd Annual meeting of the society for invertebrate pathology and 10 th International Colloquium on Invertebrate Pathology The Final Meeting of COST862 Action: Bacterial Toxins for Insect Control, Trabzon, Turkey, 11-15.07.2010, Karadeniz Technical University, Trabzon, Turkey, CD.
Pilarska, D., McManus, M., Hajek, A., Herard, F., Vega, F., Pilarski, P., Markova, G., 2000: Introduction of the entomopathogenic fungus Entomophaga maimaiga Hum., Shim. \& Sop. (Zygomycetes: Entomophtorales) to a Lymantria dispar (L.) (Lepidoptera: Lymantriidae) population in Bulgaria. Journal of Pest Science, 73:125-126.

Pilarska, D., McManus, M., Pilarski, P., Georgiev, G., Mirchev, P., Linde, A., 2006: Monitoring the establishment and prevalence of the fungal entomopathogen Entomophaga maimaiga in two Lymantria dispar L. populations in Bulgaria. Journal of Pest Science, 79:63-67.

Pilarska, D., Solter, L., Maddox, J., McManus, M., 1998: Microsporidia from gypsy moth (Lymantria dispar L.) populations in Central and Western Bulgaria. Acta zoologica bulgarica, 50:109-113.

Pilarska, D., Todorov, M., Pilarski, P., Djorova, V., Solter, L., Georgiev, G., 2013: Bioassays for detection of the entomopathogenic fungus Entomophaga maimaiga (Entomophthorales: Entomophthoraceae) in soil from different sites in Bulgaria. Acta Zoologica Bulgarica, 65:173-177.

Poinar, G. O. Jr., 1975: Entomogenous nematodes. Netherlands, E. J. Brill, 317 p.

Rashidan, K., Guertin, C., Cabana, J., 2008: Granulovirus. In: Capinera J. L. (ed.): Encyclopedia of Entomology, 2nd ed ed., Springer, p. 1653-1660.

Ravensberg, W. J., 2011: Mass production and product development of a microbial pest control agent. In: Ravensberg, W. J. (ed.): A roadmap to the successful development and commercialization of microbial pest control products for control of arthropods, Springer, New York, p. 59-127.

Reddy, K. R. K., Praveen Kumar, D., Reddy, K. R. N., 2013: Entomopathogenic fungi: a potential bioinsecticide. Kavaka, 41:23-32.

Regniere, J., 1984: Vertical transmission of disease and population dynamics of insects with discrete generations: a model. Journal of Theoretical Biology, 107:287-301.

Rehner, S. A., 2009: Molecular systematics of entomopathogenic fungi. In: S. P. Stock, Vandenberg, J., Glazer, I., Boemare, N. (eds.), Insect Pathogens: Molecular Approaches and Techniques, Wallingford: CABI, p. 145-165.

Rehner, S. A., Minnis, A. M., Sung, G. H., Luangsaard, J. J., Devotto, L., Humber, R. A., 2011: Phylogeny and systematics of the anamorphic, entomopathogenic genus Beauveria. Mycologia, 103:1055-1073.

Rowley, D. L., Popham, H. J., Harrison, R. L., 2011: Genetic variation and virulence of nucleopolyhedroviruses isolated worldwide from the heliothine pests Helicoverpa armigera, Helicoverpa zea and Heliothis virescens. Journal of Invertebrate Pathology, 107:112-126. 
Roy, H., Brodie, E., Chandler, D., Goettel, M., Pell, J., Wajnberg, E., Vega, F., 2010: Deep space and hidden depths: understanding the evolution and ecology of fungal entomopathogens. BioControl, 55:1-6.

Rühm, W., 1956: Die Nematoden der Ipiden. Parasitologische Schriftenreihe, 6:1-435.

Schowalter, T. D., 2012: Insect responses to major landscape-level disturbance. Annual Review of Entomology, 57:1-20.

Siddiqi, M.,R., 2000: Tylenchida: parasites of plants and insects. CABI Publishing, Wallingford, UK, 833 p.

Solter, L., Pilarska, D., Vossbrinck, C., 2000: Host Specifity of microsporidia pathogenic to forest Lepidoptera. Biological Control, 19:48-56.

Solter, L. F., Siegel, J. P., Pilarska, D. K., Higgs, M. C., 2002: The impact of mixed infection of three species of microsporidia isolated from the gypsy moth, Lymantria dispar L. (Lepidoptera: Lymantriidae). Journal of Invertebrate Pathology, 81:103-113.

Solter, L. F., Becnel, J. J., Oi, D. H., 2012: Microsporidian entomopathogens. In: Vega, F. E., Kaya, H. K. (eds.): Insect Pathology. Academic Press, London, p. 221-263.

St. Leger, R. J., 1993: Biology and mechanisms of insectcuticle invasion by deuteromycete fungal pathogens,. In: Beckage, N. E., Thompson, S. N.,Federici, B. A. (eds.): Parasites and pathogens of insects, vol. 2. Pathogens. Academic Press, Inc., San Diego, Califorina, p. 211-229.

Sulaiman, I., 1992: Infectivity and pathogenicity of Ascogregarina culicis (Eugregarinida: Lecudinidae) to Aedes aegypti (Diptera: Culicidae). Journal of Medical Entomology, 29:1-4.

Tabaković-Tošić, M., Georgiev, G., Mirchev, P., Tošić, D., Golubović-Ćurguz, V., 2012: Entomophaga maimaiga - new entomopathogenic fungus in the Republic of Serbia. African Journal of Biotechnology, 34:8571-8577.

Takov, D., Doychev, D., Linde, A., Draganova, S., Pilarska, D., 2012: Pathogens of bark beetles (Curculionidae: Scolytinae) and other beetles in Bulgaria. Biologia, 67:966-972.

Thomas, J. A., Telfer, M. G., Roy, D. B., Preston, C. D., Greenwood, J.J.D.,Asher, J. etal., 2004:Comparative losses of British butterflies, birds, and plants and the global extinction crisis. Science, 303:1879-1881.

Vakula, J., Gubka, A., Galko, J., Varkonda, Š., 2012: Aplikácia entomopatogénov do populácií škodcov s využitím feromónových lapačov. In: Kunca, A. (ed): Aktuálne problémy v ochrane lesa, National Forest Centre, Zvolen, p. 92-96.

Valentine,H.T., 1981:Amodel of oak forest growth under gypsy moth influence. In: Doane, C. D., McManus, M. L. (eds.): The Gypsy Moth: Research Toward Integrated Pest Management, USDA-APHIS, Forest Service Technical Bulletin 1584, p. 50-61.
Valentine, H. T . Podgwaite, J. D., 1982: Modeling the role of NPV in gypsy moth population dynamics. In: Invertebrate Pathology and Microbial Control Proceedings of III International Colloquium of Invertebrate Patholology, p. 353-356. Brighton: University of Sussex, $526 \mathrm{p}$.

Vaupel, O., Zimmermann, G., 1996: Orientierende Versuche zur Kombination von Pheromonfallen mit dem insektenpathogenen Pilz Beauveria bassiana (Bals.) Vuill. gegen die Borkenkäferart Ips typographus L. (Col., Scolytidae). Anzeiger fuer Schaedlingskunde, Pflanzen- und Umweltschutz, 69:175-179.

Vavra, J., Hylis, M., Vossbrinck, C., Pilarska, D., Linde, A., Weiser, J. et al., 2006: Vairimorpha disparis n. comb. (Microsporidia: Burenellidae): A redescription and taxonmic revision of Thelohania disparis Timofejeva 1956, a microsporidian parasite of the gypsy moth Lymantria dispar (L.) (Lepidoptera: Lymantriidae). Journal of Eukaryotic Microbiology, 53:292-304.

Vega, F. E., Kaya, H. K. (eds.): Insect Pathology (Second Edition), 2012. Elsevier Inc., San Diego, 508 p.

Vega, F. E., Meyling, N. V., Luangsa-Ard, J. J., Blackwell, M., 2012: Fungal Entomopathogens. In: Vega, F. E. and Kaya, H. K. (eds.): Insect pathology. Second edition, p. 171-220.

Vitousek, P. M., Mooney, H.A., Lubchenco, J., Melillo, J. M., 1997: Human domination of Earth's ecosystems. Science, 277:494-499.

Walker, L. R., Willig, M. R., 1999: An introduction to terrestrial disturbances. In: Walker, L. R. (ed.): Ecosystems of the World 16: Ecosystems of Disturbed Ground. Elsevier, Amsterdam, p. 1-16.

Wegensteiner, R., 2004: Pathogens in bark beetles. In: Lieutier, F., Day, K., Battisti, A., Gregoire, J-C., Evans, H. (eds.): Bark and wood boring insects in living trees in Europe, a synthesis, Kluwer, Dordrecht, p. 291-313.

Wegensteiner, R., 2007: Pathogens in bark beetles. In: Lieutier, F., Day, K. R., Battisti, A., Grégoire, J. C., Evans, H. F. (eds): Bark and wood boring insects in living trees in Europe, a synthesis. Springer, Dordrecht, p. 291-313.

Wegensteiner, R., Tkaczuk, C., Bałazy, S., Griesser, S., Rouffauda, M. A., Stradner, A. et al., 2015a: Occurrence of pathogens in populations of Ips typographus, Ips sexdentatus (Coleoptera, Curculionidae, Scolytinae) and Hylobius spp. (Coleoptera, Curculionidae, Curculioninae) from Austria, Poland and France. Acta Protozoologica, 54:219-232.

Wegensteiner, R., Wermelinger, B., Herrmann, M., 2015b: Natural enemies of bark beetles: predators, parasitoids, pathogens, and nematodes. In: Vega, F. E. , Hofstetter, R. W. (eds): Bark beetles - biology and ecology of native and invasive species. Academic press, London, p. 247-304. 
Wellington, W. G., Cameron, P. J., Thompson, W. A., Vertinsky, I. B., Landsberg, A. A., 1975: A stochastic model for assessing the effect of external and internal heterogenecity on an insect population. Research on Population Ecology, 17:1-28.

Wermelinger, B., 2004: Ecology and management of the spruce bark beetle Ips typographus - a review of recent research. Forest Ecology Management, 202:67-82.

White, P. S., Pickett, S.T.A., 1985: Natural disturbance and patch dynamics: an introduction. In: Pickett, S. T. A., White, P. S. (eds.), Ecology of Natural Disturbance and Patch Dynamics. Academic Press, New York, p. 3-13.

Yaman, M., Algi, G., Radek, R., 2019: Morphological, ultrastructural, and molecular identification of a new microsporidian pathogen isolated from Crepidodera aurata (Coleoptera, Chrysomelidae). Turkish Journal of Zoology, 43:407-415.
Yaman, M., 2020: Transmission of Microsporidium sp. between different generations of Crepidopdera aurata (Coleoptera: Chrysomelidae). Turkish Journal of Zoology, 44:248-253.

Wang, B., Lu, M., Cheng, C., Salcedo, C., Sun, J., 2013: Saccharide-mediated antagonistic effects of bark beetle fungal associates on larvae. Biology Letters, 9: 20120787.

Zúbrik, M., Barta, M., Pilarska, D., Goertz, D., Úradník, M., Galko, J. et al., 2014: First record of Entomophaga maimaiga (Entomophthorales: Entomophthoraceae) in Slovakia. Biocontrol Science and Technology, 24:710-714.

Zúbrik, M., Hajek, A., Pilarska, D., Spilda, I., Georgiev, G., Hrasovec, B. et al., 2016: The potential for Entomophaga maimaiga to regulate gypsy moth Lymantria dispar (L.) (Lepidoptera: Erebidae) in Europe. Journal of Applied Entomology, 140:565-579. 